\title{
Correlation between $\beta$-HCG and Doppler in post molar surveillance
}

\author{
Priyadarsini S.*, Gigi A.
}

Department of Obstetrics and Gynecology, Government T. D. Medical College, Alappuzha, Kerala, India

Received: 02 March 2018

Accepted: 28 March 2018

\section{*Correspondence:}

Dr. Priyadarsini S.,

E-mail: govind.priya@gmail.com

Copyright: (C) the author(s), publisher and licensee Medip Academy. This is an open-access article distributed under the terms of the Creative Commons Attribution Non-Commercial License, which permits unrestricted non-commercial use, distribution, and reproduction in any medium, provided the original work is properly cited.

\section{ABSTRACT}

Background: Gestational trophoblastic disease encompass a spectrum of neoplastic disorders that arise from placental trophoblastic tissue after abnormal fertilisation. Most molar pregnancies spontaneously resolve after uterine evacuation with no further sequelae. However, at any time during or after gestation malignant transformation may occur in approximately $10 \%$ to $20 \%$ of molar pregnancies. Quantification of $\beta \mathrm{HCG}$ is considered as the ideal method of post molar surveillance. The regression of the disease could be reliably assessed by observing the changes in low resistance flow which paralleled the gradual decrements in serial $\beta \mathrm{HCG}$ levels. To correlate uterine artery blood flow characteristics to serum $\beta \mathrm{HCG}$ levels in the follow up of patients with gestational trophoblastic disease after molar evacuation.

Methods: 50 patients with gestational trophoblastic disease after evacuation were followed up by serum $\beta \mathrm{HCG}$ titres and Doppler ultrasonography of uterine arteries. The relationship between the Doppler indices and the serum $\beta \mathrm{HCG}$ titres were evaluated by paired $-\mathrm{t}$ test and Pearsons correlation analysis.

Results: Significant negative correlations were observed between Systolic/Diastolic (S/D) ratios, Resistance Indices(RI) and Pulsatility indices (PI) and the absolute values of serum $\beta$ HCG levels, with correlation coefficients of $-0.5,-0.46$ and $-0.40(p<0.01)$. The mean values of $\beta H C G$ showed a decreasing trend from $1^{\text {st }}$ week to $4^{\text {th }}$ week. The mean value of RI, PI and S/D Ratio showed an increasing trend from $1^{\text {st }}$ week to $4^{\text {th }}$ week. However, the difference in mean values of $\beta$ HCG and Doppler indices at $1^{\text {st }}$ week and $4^{\text {th }}$ week were analysed by paired test and found to be statistically insignificant $(\mathrm{p}>0.05)$ in patients with spontaneous remission.

Conclusion: Uterine artery Doppler indices can be used as an adjunct to $\beta H C G$ for the surveillance of patients with gestational trophoblastic disease after molar evacuation to predict remission of the disease.

Keywords: Gestational trophoblastic disease (GTD), Pulsatility indices (PI), Resistance indices (RI), Systolic/diastolic (S/D) ratios, Serum $\beta$-HCG, Ultrasound doppler

\section{INTRODUCTION}

Gestational trophoblastic disease (GTD) consists of a spectrum of neoplasia, ranging from benign hydatidiform mole in which most patients has no serious sequelae to the highly malignant choriocarcinoma which without specific treatment progress rapidly to a fatal outcome. The advent of effective therapy heralded the need for effective diagnostic methods which could demonstrate malignant degeneration of hydatidiform mole at a very early stage. Thus, a tumour marker $\beta$ HCG became available and accurate Radioimmunoassay was developed by which large scale monitoring became feasible.

Conventional real - time ultrasonography is the valuable imaging modality in the diagnosis of Gestational trophoblastic disease(GTD). ${ }^{1,2}$ Nowadays because of easy availability and accessibility of ultrasonogram preliminary researches are ongoing so as to include ultrasonogram and Doppler as an adjunct to $\beta \mathrm{HCG}$ in the 
monitoring and follow up of post molar patients. Usually the post molar surveillance employs the tumour marker $\beta \mathrm{HCG}$ weekly for total regression. Abnormal $\beta \mathrm{HCG}$ regression pattern is considered to be an indication for Bmode sonography to identify

- Incomplete evacuation

- Invasive mole

- Choriocarcinoma

Ultrasound has established place in localizing tumour sites in choriocarcinoma. Doppler sonography offers a non invasive technique for quantitative functional assessment of neovascularisation, which has been shown to occur in malignant genital neoplasms. ${ }^{3}$ Similar neo vasculrisation, demonstrated by decreased vascular resistance and increased blood flow also develops in molar pregnant uterus. - $^{4}$ In invasive mole and choriocarcinoma trophoblastic invasion into myometrial tissue can be recognized as prominent color coded zones in the myometrium. These zones correspond to enlarged spiral arteries as well as to newly formed tumoral vessels. All of these vessels are characterised by high velocitylow impedence blood flow pattern. Anatomical identification of normal spiral and even radial vessels is not possible in GTD due to the presence of newly formed vessels. Low impedance to blood flow is the hallmark in trophoblastic disease in the following order of vesicular mole, invasive mole and choriocarcinoma.

We now have the knowledge and resources to eliminate morbidity and mortality associated with trophoblastic disease and the challenge which remains is how to use these to full effect in the widely differing circumstances of clinical practice around the world. The threats posed by the delayed diagnosis of trophoblastic disease includes haemorrhage, uterine perforation, stroke, rupture liver, loss of fertility, treatment failure and death. The patients managed well after molar pregnancy has little risk of these complications because persistant trophoblastic disease diagnosed early is easily controlled and uniformly curable. Quantification of $\beta \mathrm{HCG}$ is considered as the ideal method of post molar surveillance. But preliminary reports suggests that the regression of the disease could be reliably assessed by observing the changes in low resistance flow which paralleled the gradual decrements in serial $\beta H C G$ levels.

This study was planned to document the uterine artery blood flow characteristics in the follow up of patients with Gestational trophoblastic disease. The role of Doppler sonography in the management of GTD was explored by evaluating the relation between the Doppler indices and the serum $\beta \mathrm{HCG}$ levels in post molar surveillance.

\section{METHODS}

This is an observational follow up study conducted at SAT Hospital, Thiruvananthapuram for a one year period. The study group consisted of 50 patients with histopathologic diagnosis of hydatidiform mole. After basic evaluation including history, physical examination, quantitative $\beta \mathrm{HCG}$ titres and chest $\mathrm{X}$ ray, all patients were assessed by ultrasound. Suction evacuation was done as soon as diagnosis was confirmed, and specimen sent for histopathologic examination. Serum $\beta H C G$ titres and post evacuation USG with Doppler of uterine arteries were done one week after evacuation. The Doppler indices including the pulsatility index, the Pourcelots Resistance index and the ratio of peak systole /Diastole (S/D) velocities were calculated. A mean uterine artery Doppler index was calculated for each patient from their left and right uterine artery Doppler indices. $\beta \mathrm{HCG}$ was repeated every 2 weeks and a Doppler is repeated 4 weeks after evacuation. Resistance index when it reaches $>0.8$ is considered as attainment of normalcy. The pulsatility index when it reaches $>1.5$ is treated as attainment of normalcy. S/D ratio when it reaches the range 4-5 is considered as normal. In the present series $\beta H C G<20 \mathrm{~min} / \mathrm{ml}$ is taken as normal.

These patients were also evaluated for any abnormal symptoms, clinical examination for size of uterus and presence of theca lutein cyst and serum $\beta \mathrm{HCG}$ once in 2 weeks till normal values were obtained for first three consecutive weeks, and then at monthly intervals till $\beta \mathrm{HCG}$ remained normal for 6 months. During this period, they were advised barrier contraception and pregnancy was permitted in cases were $\beta \mathrm{HCG}$ titres remained normal for 6 months. Patients with plateauing or rising BHCG titer along with pathologic flow patterns in Doppler were diagnosed to have persistent trophoblastic disease and treated by a single agent chemotherapy of methotrexate.

\section{Statistical technique}

The mean value of $\beta \mathrm{HCG}$ and Doppler indices at $1^{\text {st }}$ week and $4^{\text {th }}$ week is found out. The difference in mean value of $\beta \mathrm{HCG}$ and Doppler indices in the 1st week and 4th week was tested by paired t test (two tailed). The relation between the mean Doppler indices obtained from the right and the left uterine arteries and the absolute value of serum $\beta H C G$ titres were evaluated by pearsons correlation coefficient. To find the extent of agreement between $\beta \mathrm{HCG}$ and Doppler indices phi coefficient is calculated.

\section{RESULTS}

Table 1: Distribution according to age.

\begin{tabular}{|lll|}
\hline Age in years & Number & Percentage \\
\hline$<20$ & 5 & 10 \\
\hline $20-24$ & 23 & 46 \\
\hline $25-29$ & 13 & 26 \\
\hline $30-34$ & 7 & 14 \\
\hline $35-39$ & 2 & 14 \\
\hline
\end{tabular}


Table 2: Distribution according to gravidity.

\begin{tabular}{|lll|}
\hline Gravidity & Number & Percentage \\
\hline primi & 22 & 44 \\
\hline G2 & 17 & 34 \\
\hline G3 and above & 11 & 22 \\
\hline
\end{tabular}

Table 1 and 2 shows distribution of study group according to age and gravidity. No analysis has been done on these aspects.

Table 3: Correlation between $\beta$-HCG and Doppler parameters in non chemotherapy group $(\mathrm{N}=47)$.

\begin{tabular}{|llll|} 
Characteristics & Mean & $\begin{array}{l}\text { Standard } \\
\text { deviation }\end{array}$ & Range \\
\hline$\beta$-hcg & 719.4 & 2707 & $<5-2900$ \\
\hline R.I & 0.7712 & 0.13 & $0.6-0.98$ \\
\hline P.I & 1.776 & 0.49 & $1.3-2.5$ \\
\hline S.D ratio & 3.632 & 0.78 & $2.8-4.5$ \\
\hline
\end{tabular}

Correlation coefficient (r) of

- $\quad \beta H C G$ and pulsatility index $=-0.40(\mathrm{p}<0.01)$

- $\quad \beta H C G$ and resistance index $=-0.46(p<0.01)$

- $\beta \mathrm{HCG}$ and systolic diastolic ratio $=-0.50(\mathrm{p}<0.01)$

Significant negative correlations were observed between P.I, R.I, and SD Ratio and the absolute values of serum $\beta H C G$ levels with correlation coefficients of $-0.40,-0.46$, -0.50 respectively and is statistically significant. Thus, we can infer that just like $\beta \mathrm{HCG}$ regress in post molar patients the Doppler indices shows an increasing trend and can be used in follow up of post molar patients. With $1 \mathrm{miu} / \mathrm{ml}$ decrease of $\beta$-hCG R.I increases by 0.46 , PI increases by 0.40 and SD ratio increases by 0.5 .

Table 4: Mean and standard deviation of systolicc diastolic ratio values at $1^{\text {st }}$ week and $4^{\text {th }}$ week $(N=47)$ in non- chemotheraphy group.

\begin{tabular}{|lll|ll|}
\hline & $1^{\text {st }}$ week & $4^{\text {th }}$ week & $t$ & Significance \\
\hline Mean & 2.835 & 3.632 & & \\
\hline S.D & 0.64 & 0.78 & 1.8 & P>0.05 \\
\hline
\end{tabular}

The Mean value of SD ratio at $1^{\text {st }}$ week is 2.835 and there is increase in mean value to 3.632 at $4^{\text {th }}$ weeks. The difference in mean values of SD ratio at $1^{\text {st }}$ week and $4^{\text {th }}$ week were tested by paired t test and was found to be statistically insignificant, $\mathrm{p}>0.05$ in non chemotherapy group.

The R.I showed an increasing trend from 1week to 4weeks and hence can be used in post molar follow-up. The difference in mean values of R.I at 1st week and 4th week were tested by paired t test and was found to be statistically insignificant, $\mathrm{p}>0.05$ in non chemotherapy group.
Table 5: Mean and standard deviation of resistance index values at $1^{\text {st }}$ week and $4^{\text {th }}$ week $(\mathrm{N}=47)$ in nonchemotheraphy group.

\begin{tabular}{|lllll|} 
& $1^{\text {st }}$ week & $4^{\text {th }}$ week & T & Significance \\
Mean & 0.6588 & 0.7712 & & \\
\hline S.d & 0.14 & 0.13 & 1.5 & P>0.05 \\
\hline
\end{tabular}

Table 6: Mean and standard deviation of pulsatility index values at $1^{\text {st }}$ week and $4^{\text {th }}$ week $(n=47)$ in nonchemotheraphy group.

\begin{tabular}{|lllll|} 
& $1^{\text {st }}$ week & $4^{\text {th }}$ week & $t$ & Significance \\
\hline Mean & 1.315 & 1.776 & & \\
\hline S.D & 0.33 & 0.49 & 1.5 & P>0.05 \\
\hline
\end{tabular}

The P.I showed an increasing trend from 1 week to 4 weeks. The difference in mean values of P.I at 1st week and 4th week were tested by paired t test and was found to be statistically insignificant, $p>0.05$ in non chemotherapy group.

Table 7: Mean and standard deviation of $\beta$-HCG, R.I, P.I and S/D ratio of chemotherapy group (before and after chemotherapy) $(n=3)$.

\begin{tabular}{|lll|} 
& $\begin{array}{l}\text { Before } \\
\text { chemotherapy }\end{array}$ & $\begin{array}{l}\text { After } \\
\text { chemotherapy }\end{array}$ \\
\hline$\beta$-HCG & $8435.3(10105.3)$ & $<5$ \\
\hline RI & $0.41(0.06)$ & $0.83(0.03)$ \\
\hline PI & $0.57(0.05)$ & $2.03(0.15)$ \\
\hline SD Ratio & $1.43(0.15)$ & $4.33(0.31)$ \\
\hline
\end{tabular}

The P.I showed an increasing trend from 1 week to 4 weeks. The difference in mean values of P.I at 1st week and 4th week were tested by paired $t$ test and was found to be statistically insignificant, $p>0.05$ in non chemotherapy group.

\section{DISCUSSION}

The present study is in accordance with the study conducted by omer et al. They reported correlation coefficient of $-0.5,-0.4$ and -0.46 between $\beta$-hCG and SD ratio, PI, RI respectively. ${ }^{9}$ Various other reports also suggest that colour Doppler increases the diagnostic sensitivity and significant correlation occurs between dropped $\beta$-hCG level and increased Doppler indices and hence Doppler indices can be used in post molar follow up. ${ }^{10-13}$

There is a gradual decrease in mean value of $\beta$-hCG at $1^{\text {st }}$ week (5118.3) to the value at 4 weeks (719.4), in the non chemotherapy group. In almost $90 \%$ of cases $\beta$-hCG became normal by 8 weeks. Bagshawe et al reported that $42 \%$ of cases attained normal $\beta$-hCG values by 56 days post evacuation and none of them developed sequelae. ${ }^{14}$ 
As the disease regress the Doppler indices increase and show the same trend as $\beta$-hCG to attain normal values. ${ }^{15}$ The mean value of SD ratio showed an increasing trend from $1^{\text {st }}$ week to $4^{\text {th }}$ week (2.835 to 3.632). Yalsin OT et al reported a mean SD ratio of 5.10 at the last evaluation in patient with spontaneous regression and 2.27 in patients with persistent disease. ${ }^{9}$ The mean value of PI, RI also showed an increasing trend from $1^{\text {st }}$ week to $4^{\text {th }}$ week and this can be compared to other reports.

In the present study three patients who had persistent disease determined by plateauing or rising $\beta$-hCG titres had significantly lower SD ratio, RI, PI value than those 47 patients who had spontaneous regression with normal $\beta$-hCG titres. Hence Doppler indices would discriminate those patients with persistant disease.

\section{CONCLUSION}

Serum $\beta$-hCG and Doppler indices are complimentary modalities that can be used in follow up of postmolar patients. When compared to $\beta$-hCG, Doppler is a quicker method in diagnosis of persistent trophoblastic disease. In patients who received chemotherapy, there was a significant increase in Doppler indices after chemotherapy and uterine artery Doppler is effective to asses the improvement in the non chemotherapy as well as in the chemotherapy group.

Funding: No funding sources

Conflict of interest: None declared

Ethical approval: The study was approved by the Institutional Ethics Committee

\section{REFERENCES}

1. Kohorn EI, McCarthy SM, Taylor KJ. Nonmetastatic gestational trophoblastic neoplasia. Role of ultrasonography and magnetic resonance imaging. J Reprod Med. 1998 Jan;43(1):14-20.

2. Reid MH, McGahan JP, Gooperberg PL. Sonographic evaluation of hydatidiform mole. Clin. Obstet Gynecol. 1988;15:491-6.

3. Develioğlu OH, Bilgin T, Yalçin ÖT, Özalp S, Ozan $\mathrm{H}$. Adjunctive use of the uterine artery resistance index in the preoperative prediction of myometrial invasion in endometrial carcinoma. Gynecol Oncol. 1999 Jan 1;72(1):26-31.

4. Kurjak A, Zalud I, Predanic M. Transvaginal color Doppler in early pregnancy: rational and clinical potential. J Perinatal Med. 1994;22(6):475-82.
5. Bagshawe KD, Long MG. Doppler assessment of uterine circulation and clinical behaviour of gestational trophoblastic tumors requiring chemotheraphy. Br J Cancer. 1992;66(5):883-7.

6. Hsieh FJ, Wu CC, Lee CN, Chen TM, Chen CA, Chen FC et al. Vascular patterns of gestational trophoblastic tumors by color Doppler ultrasound. Cancer. 1994 Oct 15;74:2361-5

7. Hsieh FJ, Wu CC, Chen CA, Chen TM, Hsieh CY, Chen HY. Correlation of uterine hemodynamics with chemotherapy response in gestational trophoblastic tumors. Obstet Gynecol. 1994 Jun;83(6):1021-5.

8. Tepper R, Shulman A, Altaras M, Goldberger S, Maymon R, Holzinger M, Beyth Y. The role of color Doppler flow in the management of nonmetastatic gestational trophoblastic disease. Gynecologic and obstetric investigation. 1994;38(1):14-7.

9. Yalcin OT, Ozalp SS, Mete Tanir H. Assessment of gestational trophoblastic disease by Doppler ultrasonography. European J Obstet Gynaecol Reprod Biol. 2002;103(1);83-87.

10. Bidziński M, Sobiczewski P, Derlatka P, Pietrzak K, Wierzba W. Clinical usefulness of color doppler flow examination during treatment of gestational trophoblastic disease. Ginekologia Polska. 1999 Feb;70(2):88-92.

11. Carter J, Fowler J, Carlson J. Trans vaginal colour flow Doppler sonography in the assessment of gestational trophoblastic disease. J Ultrasound Med. 1993;12:595-9.

12. Feng C, Leix, Liu J. Diagnostic value of colour Doppler flow in imaging in gestational trophoblastic disease. Zhonghua $\mathrm{Fu}$ Chan ke Za Zhi. 1996;31(4):209-11.

13. Shimamoto K, Sakuma S, Ishigaki T, Makino N. Intratumoral blood flow: evaluation with color Doppler echography. Radiology. 1987 Dec;165(3):683-5.

14. Bagshawe KD, Dent J, Webb J. Hydatidiform mole in England and Wales 1973-83. Lancet. 1986 Sep 20;328(8508):673-7.

15. El Aal DE, El Senosy ED, Kamel MA, Atwa M. Uterine artery Doppler blood flow in cases of hydatidiform mole and its correlation with $\beta$-hCG. Eur J Obstet Gynecol Reprod Biology. 2003 Dec $10 ; 111(2): 129-34$.

Cite this article as: Priyadarsini S, Gigi A.

Correlation between $\beta$-HCG and Doppler in post molar surveillance. Int J Reprod Contracept Obstet Gynecol 2018;7:1836-9. 